\author{
Wanda Supa* \\ Uniwersytet w Białymstoku \\ https://orcid.org/0000-0001-9528-8980
}

\title{
Postsowiecka rzeczywistość w świetle „transmetarealizmu”. Powieść Władimira Makanina Dwie siostry i Kandynsky
}

Streszczenie: W artykule omówiono problematykę i poetykę późnej powieści Władimira Makanina Dwie siostry i Kandynsky. Możliwości transmetarealizmu, czyli strategii syntezy osiągnięć realizmu różnych epok z postmodernizmem, pisarz wykorzystał dla odzwierciedlenia aktualnych problemów rosyjskiej postsowieckiej rzeczywistości. W utworze wykreowano nowe typy bohaterów (m.in. oligarchów i polityków), scharakteryzowano zjawisko sponsoringu w polityce, relacje między płciami we współczesnym społeczeństwie, donosicielstwo jako uciążliwy balast rosyjskiej historii, rolę sztuki wysokiej w zmaganiu się bohaterów z trudnymi warunkami życia w Rosji kapitalistycznej. Finezyjne zabiegi intertekstualizacji pozwalają odnosić Makaninowskie obrazy i idee do kontekstu rosyjskiej klasyki i wartości uniwersalnych.

Słowa-klucze: transmetarealizm, rzeczywistość postsowiecka, polityka, relacje płci, systemy wartości.

\footnotetext{
* Wanda Supa - prof. dr hab., profesor zwyczajny w Instytucie Filologii Wschodniosłowiańskiej Uniwersytetu w Białymstoku, badaczka współczesnej literatury rosyjskiej i białoruskiej; autorka monografii: Twórczość Walentina Katajewa (1996), Biblia a współczesna proza rosyjska (2006), W kręgu problemów prozy rosyjskiej końca XX-początku XXI wieku: tematy i konwencje (2018).
} 


\section{Post-Soviet reality in the light of "transmetarealism".} The novel by Vladimir Makanin Two Sisters and Kandinsky

Summary: The article discusses the problems and poetics of Vladimir Makanin's late novel Two Sisters and Kandinsky. The writer used the possibilities of transmetarealism, i.e. the strategy of synthesising the achievements of realism of different epochs with postmodernism, to reflect the current problems of the Russian post-Soviet reality. The work creates new types of heroes (i.e. oligarchs and politicians), characterises the phenomenon of sponsorship in politics, gender relations in contemporary society, denunciation as a significant burden of Russian history, the role of high art in the heroes' struggle against difficult living conditions in capitalist Russia. Sophisticated intertextuality procedures allow for relating Makanin's images and ideas to the context of Russian classics and universal values.

Key words: transmetarealism, post-Soviet reality, politics, gender relations, value systems.

Powieść znanego pisarza rosyjskiego Władimira Makanina (1937-2017) Dwie siostry i Kandynsky (Две сестры и Кандинский, 2011) wprowadza czytelnika w atmosferę lat 90. XX wieku, a więc schyłku Gorbaczowowskiej przebudowy i początku transformacji ustrojowej, kiedy w różnych grupach społecznych dominowała nadzieja, iż Rosja stanie się krajem w pełni demokratycznym, oraz że problemy nękające jej obywateli w czasach socjalizmu zostaną szybko rozwiązane. Z perspektywy lat 10. obecnego stulecia przełomowy okres między przebudową, rozpadem ZSRR a prezydenturą Władimira Putina jawi się niemal jako „czarna dziura” niedawnej historii.

Główne przyczyny znikomej wiedzy o nim to burzliwość i dynamizm przemian, destabilizacja życia społecznego, dezinformacja w mediach, słabość państwa, historyczna konieczność dekonstrukcji mentalności w przypadku znacznej części rosyjskiego społeczeństwa i adaptacji do nowych, nieznanych warunków, inicjująca zmiany w samoidentyfikacji. Stąd w publicystyce gazetowej i w pracach naukowych z dziedziny socjologii, historii czy historii prawa 
spotykamy określenia typu „burzliwe” bądź „ostre” lata 90. XX wieku, a w literaturze oraz w języku potocznym metaforycznie „czas historycznie nieuniknionej smuty” czy „zły sen”" , który jednak nie ulotnił się całkowicie, ponieważ właśnie w tym czasie w Rosji zaczęły się kształtować funkcjonujące do dzisiaj mechanizmy, warunkujące życie jednostek oraz całego społeczeństwa.

Zewnętrzne oznaki przemian w interesującym nas wycinku czasowym to wyjście z podziemia dysydentów, zainteresowanie polityką ze strony sporej części przeciętnych obywateli i równolegle - przeorientowanie działalności wielu członków radzieckiej nomenklatury i służb wewnętrznych, którzy wykorzystywali nadarzające się okazje (w pierwszej kolejności luki prawne i dostęp do informacji o podejmowanych na najwyższym szczeblu władzy decyzjach ekonomicznych) do przejmowania niesprywatyzowanego wcześniej denacjonalizowanego majątku państwowego i bogacenia się². Szybko zatarła się granica między legalnością a bezprawiem, gdyż w Rosji kapitalizm oligarchiczny typu mafijnego rodził się w atmosferze nadużyć, oszustw i kradzieży, oczywiście utrzymywanych w tajemnicy i do dzisiaj nie w pełni zbadanych ani przez dziennikarzy czy politologów, ani przez literaturę. Pomimo braku syntetycznych opracowań naukowych nie budzi wątpliwości fakt, iż podział rosyjskiego bogactwa $\mathrm{w}$ okresie transformacji ustrojowej był skrajnie niesprawiedliwy ${ }^{3}$, w rezultacie czego w krótkim czasie powstały wielkie fortuny, a z drugiej strony udziałem milionów byłych obywateli radzieckich stała się dotkliwa bieda.

Zasygnalizowane powyżej i pochodne od nich zjawiska zostały zobrazowane w omawianej powieści Makanina. Już na samym początku utworu autor książki w wypowiedzi jednej ze swoich bohaterek wprowadza werbalnie takie znaki charakteryzowanego dziesięciolecia, jak „thumy zdezorientowanych ludzi” na ulicach Moskwy, panoszenie się złodziei i żebraków, „bezdomne głodne dzieci z wilczym spojrzeniem”, puste sklepy (które wkrótce zapełniły się

1 Por. J. Jaffe, Pokolenie Putina. Kim sa dziś młodzi Rosjanie?, www.national-geographic/ludzie/pokolenie-Putina [dostęp: 08.11.2018]

2 W czasie rządów Borisa Jelcyna oligarchowie kontrolowali prawie połowę rosyjskiej gospodarki. Zob. C. Ericson, Oligarchowie, przeł. H. Jankowska, Warszawa 2014 oraz tenże, Oligarchowie. Pieniadze i władza w kapitalistycznej Rosji, (wywiad), [w:] https://www.nesweek.pl/swiat/oligarcgowie-w-rosji [dostęp: 12. 11. 2018 r.].

3 Por. Z. Raczyński, Między oligarchiq a biedota, [w:] https://www.polityka.pl/swiat/2772640/życie-Rosji-między-oligarchią-a biedotą [dostęp: 29.11.2018r.]. 
towarami z importu), bijatyki w kolejkach po wódkę, rozkwit handlu wymiennego itp. Wykreowane przez niego postacie i ich sytuacje życiowe ujawniają o rosyjskiej współczesności oraz o naturze współczesnego człowieka prawdy mroczne i niepochlebne.

Władimir Makanin pozostaje jednym z niewielu pisarzy, którzy w konwencji realistycznego prawdopodobieństwa wykreowali postaci polityków różnych szczebli i naświetlili kwestię związku polityki z biznesem. Analizowany utwór jest mocno osadzony w kontekście społeczno-politycznym głównie poprzez dobór bohaterów oraz zdarzeń: najważniejsze postaci utworu to córki powszechnie szanowanego, już nieżyjącego dysydenta Tulcewa, początkujący polityk Artiom Sigajew, niespełniony muzyk rockowy Maksim Kwinta, jego ojciec - emerytowany pracownik KGB, bezdomny chłopiec Kola Ugriumcew, sponsor Artioma, reprezentujący nowych oligarchów, anonimowy właściciel kawiarni - reprezentant powstającej w Rosji klasy średniej.

Tłem dla rozwoju pierwszoplanowych wątków - miłosnego i rozliczeniowego w stosunku do radzieckiej przeszłości są wydarzenia typu przygotowania do wyborów do Dumy Moskiewskiej, galopująca (czterocyfrowa) inflacja, rozpad bądź likwidacja starych instytucji i tworzenie się nowych, radykalna zmiana polityki kulturalnej, w tym oficjalnego stosunku do sztuki awangardowej, zilustrowana przez fakt, iż Olga Tulcewa prowadzi muzeum-studium Wassilego Kandynsky'ego.

Za zmiany, tak jak zawsze, najwyższą cenę płacą najsłabsi, co wymownie potwierdza sytuacja bezdomnego nastolatka. Bohaterowie, zwłaszcza Olga i Inna, młode wykształcone i wyemancypowane kobiety, wychowane w kulcie wartości przedrewolucyjnych i kultywujące dziewiętnastowieczne tradycje społecznikowskie, żyją jeszcze ideami przebudowy, nadziejami, jakie obudziła, mglistą wiarą, iż wszystko może zmienić się na lepsze, jednak ani w świecie rzeczywistym $^{4}$, ani w wykreowanym w powieści do tego nie dochodzi. Sygnalizowana jest natomiast atmosfera rozczarowania, zagubienia bohaterów,

4 Politolodzy przekonują, iż w Rosji nie tylko nie zbudowano instytucji demokratycznych, lecz coraz wyraźniej kraj ten staje się państwem autorytarnym, pewnym przedłużeniem ZSRR, gdyż odnawiane są sowieckie narzędzia represji i wykorzystywane np. w zwalczaniu opozycji. Zob. A. Podrabinek, Dysydenci. Nieuleczalnie niepostuszni, Warszawa 2017 oraz N. Pietrow, Rosja traktuje zbrodnie ZSRR jako swoje własne, rozm. M. Puchłowski, [w:] https://dzieje.pl/aktualności/nikita-pietrov-rosja-traktuje [dostęp: 12.10.2018 r.]. 
prowadząca do degradacji osobowości konieczność szukania przez nich kompromisów. Ukazując różne postawy wobec życia i zróżnicowane horyzonty wartości pisarz sygnalizuje, iż spuścizna radzieckiego totalitaryzmu ujawnia się w pierwszej kolejności w braku przygotowania jednostek do samodzielności, do właściwego i umiejętnego korzystania z wolności, z nowych możliwości.

Jak sygnalizujemy w tytule niniejszego artykułu, powieść Makanina ze względu na wypracowaną przez autora oryginalną strategię artystyczną można zaliczyć do transmetarealizmu ${ }^{5}$, rozumianego jako swobodna synteza możliwości przedstawiania wypracowanych przez wszelkie odmiany realizmu (od klasycznego po surrealizm) oraz modernizmu i zwłaszcza postmodernizmu w celu tematyzowania ważkich problemów ontologicznych i etycznych. Synteza tego typu sprzyja dużej kumulacji wpisywanych w tekst sensów i przesłań, powstawaniu rozległych konotacji odbiorczych, aktywizowaniu zadomowionych w kulturze metafor, wzmacnianiu oddziaływania etycznego i estetycznego przy zachowaniu prawdopodobieństwa.

Charakter epoki Makanin przedstawia, patrząc na rzeczywistość pozaliteracką poprzez pryzmat sprawdzonych matryc intertekstualnych, „zakorzenionych w receptywnej tradycji znaków"6, wywodzących się z dzieł Nikołaja Gogola, Fiodora Dostojewskiego, Antona Czechowa, Maksima Gorkiego, Michaiła Bułhakowa, Aleksandra Sołżenicyna i innych. Swoją specyficzną organizację makaninowski „,nadtekst” czy „metatekst o luźnej strukturze” zawdzięcza w pierwszej kolejności nawiązaniu do klasycznych sytuacji fabularnych, występujących w dramatach Czechowa (tytułowe dwie siostry, górujące nad otoczeniem inteligencją i moralnością, skazane jednak na życiowe niepowodzenie, na niemożność realizacji swoich marzeń), problematyki rodem z Dostojewskiego, z którym, jak już odnotowywano wielokrotnie, Makanin prowadzi bezustanny dialog prawie w każdym ze swoich utworów oraz do specyfiki przedstawieniowej malarstwa (tytułowy Kandynsky).

5 Termin ten wprowadziła N. Iwanowa w art. Преодолевщие постмодернизм, «ЗнаMя» 1998, № 1, s. 201. Wprawdzie budzi on kontrowersje, ale bywa stosowany przez badaczy rosyjskiej literatury współczesnej i uznajemy go za przydatny zwłaszcza do charakterystyki późnej twórczości Makanina.

6 О. Калашникова, «Две сестры и Кандинский» в индивидуально-авторском сверхтексте В. Маканина, «Держава та регіони», серия: «Гуманітарні наукі» 2018, 1, c. 10 . 
W Dwóch siostrach ... dialog zarówno z Czechowem, jak i z Dostojewskim dotyczy nagłej konieczności zmian mechanizmów postępowania (zwłaszcza w przypadku prześladujących bohaterów niepowodzeń) i rodzenia się nowych ludzkich cech w zmienionej sytuacji społeczno-ekonomicznej, a także współoddziaływania tego, co wieczne, oraz tego, co zostało ukształtowane przez tłamszący jednostkę system sowiecki z możliwościami i wymogami nowego ustroju.

Konsekwencją nawiązania do spuścizny Czechowa-dramaturga stała się teatralizacja wszystkich elementów (i warstw) tekstu omawianej powieści; przejawia się ona w pierwszej kolejności w wyrazistości charakterystyk bohaterów, zawężonej przestrzeni (studium Olgi i kawiarnia mieszcząca się w tym samym budynku) oraz obfitości dialogów - nośników autocharakterystyki poprzez mowę niezależną z uwzględnieniem dozowania informacji w celu odsłonięcia sedna osobowości (ros. стадиальность во введении слова героя $\left.{ }^{8}\right)$. Z kolei obecność nazwiska Kandynsky'go w tytule i wybór na miejsce akcji jego studium z reprodukcjami obrazów zwraca uwagę na związek między jego techniką malarską a organizacją przekazu narracyjnego i wypowiedzi postaci utworu - słowu trzecioosobowego personalnego narratora (Olga) i nakładającemu się na nie słowu nadrzędnego narratora autorskiego odpowiadają linie z obrazów, wypowiedziom bohaterów - plamy i punkty9.

Dodajmy - obrazom jako całości odpowiadają sceny pełne dramatyzmu i nieoczekiwanych zwrotów akcji (kontrapunkty), co w ogólnym zarysie ma związek z intensywnością barw i bogactwem elementów graficznych (głównie geometrycznych) z obrazów ,pioniera awangardy”, a symboliczne kojarzenie „poziomych i pionowych kresek i linii odchylających się na wszystkie strony oraz plam barwnych, skupiających się i rozsypujących"10 również w świecie obrazów tworzonych słowem daje efekt „zagłębiania się w rzeczywistość”. Ponadto malarski rytm kompozycyjny i płynność rozedrganych ulotnych linii pisarz próbuje przenosić na prezentacje życia duchowego swoich postaci. Jak

8 В. Шуников, Синтез эпоса и драмы в романе В. С. Маканина «Две сестры и Кандинский», «Вестник ТБГУ», серия «Филология» 2014, 3, с. 148.

9 С. Ким, (рецензия), ibookyou/2015/06/24/dve-setry-i-kandynskiy [dostęp: 22.11.2018 r.].

10 W. Kandynsky, Punkt a linia i płaszczyzna. Przyczynek do analizy elementów malarskich, przeł. S. Fijałkowski, Warszawa 1986, s. 12. 
czytamy w powieści: „krzyczące jaskrawe obrazki... zadziwiająco zgodnie zrosły się z odradzającym [po upadku ZSRR - W. S.] życiem"11.

Starsza z sióstr, Olga, którą można nazwać współczesną Tatianą Łariną z Eugeniusza Oniegina czy też literacką krewną szlachetnych bohaterek Turgieniewa, wielokrotnie podkreśla, iż najważniejszą w jej życiu jest sztuka Kandynsky'go, ale ważną rolę wyznacza ona także prawdziwej miłości, wyborowi partnera. Pełne zaangażowania z jej strony romanse, i te z przeszłości, które mgliście wspomina, oraz dwa zobrazowane na stronicach powieści, wprowadzają czytelnika w złożone kwestie relacji płci we współczesnym świecie i unaoczniają, iż obecnie, niezależnie od bagażu historyczno-politycznego, zmienia się nie tylko relacja między płciami (w kierunku partnerskiej), ale też sama istota męskości i kobiecości, oraz że wybór życiowego partnera w dzisiejszej Rosji jest niezwykle trudny, przy przestrzeganiu określonych zasad etycznych i bezkompromisowości prawie niemożliwy ze względu na kryzys męskości.

Wszyscy wykreowani na stronicach powieści mężczyźni to ludzie słabi, duchowo ułomni, wyposażeni w cały wachlarz wad, uniemożliwiających bohaterce ich akceptację. W wypowiedziach pozaliterackich Makanin podkreślał, iż lata 90. XX stulecia nie wykreowały swoich bohaterów, że w związku z gruntownym przewartościowaniem wartości zdewaluowały się nie tylko wzorce radzieckie, lecz w dobie przemian „zgaśli też bohaterowie podziemia”12. Część z nich stała się elitą postsowieckiego społeczeństwa i zapomniała o dawnych ideałach, część z trudem nadal poszukuje swojego miejsca w nowej rzeczywistości, i to do tej drugiej grupy należą wykreowani w powieści mężczyźni.

W pierwszej części/akcie dramatycznym utworu oprócz tytułowych sióstr rolę pierwszoplanową gra młody, charyzmatyczny, niezwiązany z dawną nomenklaturą polityk, w przeszłości walczący o wolną sztukę pracownik pionu kultury Artiom Sigajew, zwany Konstantą, aktualny ukochany Olgi. Po zmianie ustroju kariera polityczna w Rosji wydawała się byłym dysydentom na wyciągnięcie ręki, ale w praktyce okazała się trudna do zrealizowania i upadki

11 В. Маканин, Две сестры и Кандинский, Москва 2011, изд. Эксмо, с. 6 [tt. тоје W. S.]

12 Tegoż, «Две сестры и Кандинский», интервью с писателем 20.04.2013, http://nekrasov1979.livejournall.coom/114556.html [dostęp: 04.02.2019 r.]. 
początkujących działaczy po krótkich wzlotach w latach 90 . XX wieku zdarzały się tam znacznie częściej, niż w innych krajach. O powodzeniu decydowały nie indywidualne predyspozycje czy program wyborczy, lecz umiejętność znalezienia sponsorów i zawierania nie zawsze „czystych” układów.

Wprowadzając czytelnika w świat polityki uprawianej w Rosji po upadku ZSRR, pisarz scharakteryzował mechanizmy ówczesnego sponsoringu, z którego zmuszeni byli korzystać zarówno początkujący, jak i doświadczeni politycy, nie wyłączając głowy państwa Borisa Jelcyna, gdyż skarb tego państwa wtedy był pusty. Odbiorca dowiaduje się, iż kampanię wyborczą Konstanty finansował tajemniczy Szef, wspierający oprócz Artioma jeszcze dwóch innych działaczy, posiadający sztab ludzi, gotowych ślepo wykonywać jego polecenia.

Makaninowski „Szef” to oczywiście uogólniony groteskowy portret oligarchów doby Jelcynowskiej ${ }^{13}$, reprezentujący tych, którzy błyskawicznie przewidzieli, iż możliwość sterowania politykami może się okazać dla nich niezwykle opłacalna. Sceny z pierwszej części powieści ilustrują, że w Rosji już w latach 90. niniejszego wieku wykrystalizował się nowy podział na ludzi potężnych i wpływowych oraz na uzależnioną od nich resztę. Nowi biznesmeni są bezwzględni, pewni swojej siły i bezkarności. Narzucają swoją wolę bezdyskusyjnie drogą zastraszania (pobiciem lub śmiercią) i poniżania opornych. Gdy przypadkowo Artiom został zdemaskowany jako co prawda niegroźny, ale jednak współpracujący ze służbami wewnętrznymi donosiciel, natychmiast zerwano z nim współpracę i uzmysłowiono mu jego małość i nicość.

Przypadek Artioma wiele mówi o problemach ze spuścizną po ZSRR w dziedzinie prawa i etyki, o skomplikowanych relacjach między pojęciami „obowiązek”, „zasługa” (dla państwa) a przestępstwo moralne, niekarane przez prawo ani w czasach radzieckich, ani później, ale w oczach dysydentów i w czasach postsowieckich w opinii publicznej potępiane. W światopoglądzie analizowanego utworu „samodonosy” są traktowane jako choroba wielu inteligentów rosyjskich, którzy podejmowali współpracę ze służbą bezpieczeństwa ze względów ideowych w dobrej wierze, powodowani pragnieniem po-

13 C. Ericson w przywoływanym już źródle podaje informację, iż aresztowany za rządów W. Putina Fiodor Chodorkowski miał na liście swoich płac stu deputowanych do Dumy Państwowej, gotowych zawsze głosować zgodnie z jego instrukcjami. Zob. C. Ericson, Oligarchowie. Pieniadze $i$ wtadza ..., dz. cyt. 
prawiania świata zastanego, wnoszenia weń spokoju i harmonii ${ }^{14}$. W świecie polityki jakakolwiek współpraca $\mathrm{z}$ dawnym reżimem to oczywiście argument do zwalczania konkurencji i pozbywania się kandydatów, którzy przestają się podobać, chociaż, jak powszechnie wiadomo, przeszłość wielu rosyjskich (i nie tylko) polityków wcale nie jest kryształowa. Artiom wydaje się jednak w pewnym stopniu literackim potomkiem bohaterów Dostojewskiego, zwłaszcza Raskolnikowa ze Zbrodni i kary - natychmiast rezygnuje on z kariery politycznej, jako swojego rodzaju karę i jednocześnie katharsis wybierając wyjazd na prowincję i pracę w zawodzie nauczyciela. Bohater ten jawi się czytelnikowi jako jednostka słaba, neurotyczna i egoistyczna, niezdolna do walki o własne idee.

W drugiej części utworu występuje postsowiecki „męski” bohater innego typu. Kolejny ukochany Olgi to przystojny młody mężczyzna, posiadający zewnętrzne fizyczne atrybuty męskości: rosły i silny, wygadany, utalentowany muzyk rockowy o pseudonimie Maksim Kwinta. To przykład człowieka zawładniętego ideą i marzeniami, fanatycznie wierzącego w możliwość osiągnięcia celu. Z nim i z członkami jego muzycznego zespołu związana jest „nieupolityczniona przestrzeń powieści” ${ }^{15}$, domena wolności, a raczej lekkomyślności czy głupoty. Zachowanie Maksima i członków jego zespołu uzmysławia, iż olbrzymia ilość ludzi (w każdym państwie) żyje nie tylko z dala od polityki, ale nawet nie zauważa tego, co politykom spędza sen z powiek. Apolityczność nie ułatwia jednak automatycznie znalezienia miejsca w życiu muzycy, których nowa muzyka nie podoba się ani znawcom, ani przeciętnym, zajętym swoimi sprawami obywatelom, na kapitalistycznym rynku są zupełnie bezwartościowi.

Maksim przypomina marzycielskich, nieumiejących sobie radzić w bezwzględnej rzeczywistości bohaterów rosyjskich baśni, z tym wszakże, iż nie zasługuje on na dobrych pomocników. Makanin pokazuje, iż w sytuacji, gdy państwo przestało sponsorować kandydatów na artystów, skazani są oni na

14 В. Маканин, интервью М. Базаровой, Теперь интеллект не ценится, но терпится, 1.09.2011, www.chaskar.ru/article/vladimir_makanin_sejchas_intellekt, [dostęp: 02.01.2019 r.].

15 В. Маканин, «Две сестры и Кандинский», интервью с писателем 20.04.2013..., dz. cyt. 
samych siebie i łaskę bogatych. Ich sytuacja wcale nie jest lepsza, niż kandydatów na polityków. Drugi partner Olgi to współczesna wersja rosyjskiego żigolaka czy niebieskiego ptaka, nie dostrzegającego twardych mechanizmów rzeczywistości. Mężczyźni tego typu nawet nie polują na wielkie fortuny, lecz korzystają z każdej okazji, by wyciągać pieniądze od zakochanych w nich kobiet. To kolejny mężczyzna słaby, niespełniony, wręcz żałosny, który w pogoni za swoją pasją utracił ludzką godność.

Jak już sygnalizowaliśmy, oba powieściowe romanse Olgi stanowią bogaty materiał do określania współczesnych paradygmatów „męskości”l6 i „kobiecości”. Zmiany zachodzące w tej niezwykle ważnej dziedzinie antropologii w Rosji mają wiele wspólnego z tendencjami światowymi, ale mają też swoją historycznie uwarunkowaną specyfikę. W kulturze zachodnioeuropejskiej i amerykańskiej tradycyjny wzorzec męskości zmienił się głównie z powodu rozwoju techniki, rozkwitu konsumpcjonizmu, emancypacji kobiet, zmiany funkcji rodziny jako podstawowej komórki społecznej (zjawisko „singli”, związków homoseksualnych), feminizacji mężczyzn i maskulinizacji kobiet. W Rosji warunki bytu i inna sytuacja demograficzna pozostawiły na wykładni męskości i kobiecości widoczne ślady: w XX wieku wojny i represje zachwiały demograficzne proporcje między płciami i taki stan rzeczy utrzymuje się do tej pory - według statystyk w 2010 roku w kraju tym żyło 65 milionów mężczyzn i 76 milionów kobiet ${ }^{17}$.

Kolejnym czynnikiem, eliminującym rosyjskich mężczyzn z życia populacji, od dawna stał się alkoholizm. Po rewolucji październikowej kobiety radzieckie zostały wyzwolone spod patriarchatu i wielu ograniczających ich możliwości zwyczajów, ale uzyskana przez nie wolność przejawiła się głównie w tym, iż zastąpiły mężczyzn w tradycyjnie męskich zawodach. Wiele radzieckich kobiet musiało łączyć pracę zawodową z wychowaniem dzieci w pojedynkę (kryzys ojcostwa). Kobieta stała się równa mężczyźnie w większości sfer życia, zwłaszcza zawodowej, kulturalnej, prywatnej, nawet w politycznej, chociaż w Rosji kobiet-polityków wciąż prawie nie ma.

16 Zob. Męskość w kulturze wspótczesnej, red. A. Radomski, B. Truchlińska, Lublin 2008 oraz Z. Melosik, Kryzys męskości w kulturze wspótczesnej, Poznań 2002.

17 Por. Л. Улицкая, Священный мусор, Санкт-Петербург 2012, с. 100. 
Nowa sytuacja społeczno-ekonomiczna zakwestionowała radzieckie paradygmaty zarówno męskości, jak i kobiecości. W czasach radzieckich, kiedy ideologia oferowała recepty na wszystko, zwłaszcza na ludzkie szczęście, oficjalna propaganda i literatura wylansowały i utrwaliły specyficzne wzorce: mężczyzna „prawdziwy” to bojownik o rewolucyjne (później radzieckie) idee, gotowy za nie oddać życie, obrońca ojczyzny, budowniczy nowego ładu, nowego „pięknego" świata - wynalazca, odkrywca, rekordzista w swoim zawodzie lub w sporcie - i dopiero na dalszym planie głowa i podpora rodziny (przy lekceważeniu jej materialnych potrzeb), ojciec, stanowiący wzór dla dzieci. W życiu rzeczywistym często wymuszano heroizm i ofiarnictwo (zwłaszcza na wojnach, ale także w pracy zawodowej) przy pomocy oddziaływania na psychikę przy pomocy odpowiednich metod wychowawczych i systemu surowych kar.

Wzorzec kobiety różnił się od paradygmatu męskiego właściwie tylko oczekiwaniami w sferze macierzyństwa i wychowywania dzieci. Natomiast rzeczywistość kapitalistyczna na plan pierwszy wysunęła pogoń za sukcesem, dobrami materialnymi, szczęściem, w przypadku kobiet lekceważoną w czasach radzieckich urodę i elegancję. Kobiety radzieckie nie potrzebowały ze strony mężczyzn gwarancji bezpieczeństwa materialnego, ale potrzebowały miłości i oczywiście po rozpadzie ZSRR to się nie zmieniło. Makanin pokazuje, iż jego bohaterki też jej pragną, ale nie znajdują - Olga przeżywa krótkotrwałe romanse, Inna (nazywana przez niektórych krytyków „bladą kopią Olgi”) zakochuje się w mężczyznach porzuconych przez siostrę, ale bez wzajemności. Przyczyną życiowego niepowodzenia Olgi jest jej ideowość i zasadniczość, kultywowanie wartości uniwersalnych. Bohaterka wyposażona w takie cechy oraz w wysoką samoświadomość za główne wady postsowieckich mężczyzn uważa egoizm, nieodpowiedzialność, przedmiotowe traktowanie kobiet. Makaninowskie postsowieckie kobiety lepiej sobie radzą w kapitalistycznej Rosji niż mężczyźni, ale szczęścia im to nie przynosi. Znana pisarka Ludmiła Ulicka w wypowiedziach publicystycznych stwierdza, iż męska świadomość nie nadąża za zmianami tak szybko, jak kobieca. Dotyczy to też walki o równouprawnienie oraz dążeń do doskonalenia człowieczeństwa ${ }^{18}$. 
W rozdziale trzecim Makanin wraca do зщкгыяяфтупщ już w części pierwszej wciąż w Rosji aktualnego i niezwykle złożonego problemu donosicielstwa. Dzięki wprowadzeniu nowej postaci literackiej problem ten został przeniesiony w szerszy, uniwersalny wymiar. Makanin wykreował tym razem donosiciela „zawodowego”, pracownika służb wewnętrznych, który donosił na przyjaciół i znajomych, wyolbrzymiając ich „,przestępstwa” lub fałszując fakty i w ten sposób przyczynił się do aresztowania kilkudziesięciu osób. Ojciec Maksima Siergiej Siergieicz, zwany Ojczulkiem, na pierwszy rzut oka sympatyczny gadatliwy staruszek, reprezentuje rzesze tych, którzy byli filarami reżimu. Jak wiadomo, zjawisko donosicielstwa w różnych formach istniało od zarania dziejów i istnieje nadal pewnie we wszystkich krajach i w zależności od uwarunkowań i okoliczności może przyjmować różny status aksjologiczny. Ten sam czyn najczęściej przez jedną ze stron bywa odbierany jako zasługa czy bohaterstwo, przez drugą zaś jako podłość czy zdrada.

Historia wielokrotnie dowodzi, że ocena faktów przekazywania tajnych, często zdobytych podstępem informacji zależy od zmieniających się czynników, zwłaszcza ustroju czy tylko ekipy rządzącej, światopoglądu oceniającego itp. W Rosji jednak zjawisko donosicielstwa ma wymiar szczególny, gdyż charakteryzuje ono specyficzne relacje na linii władza - społeczeństwo, zarówno w czasach caratu, jak i radzieckich oraz współcześnie. W okresie przedrewolucyjnym było ono rozpowszechnione jako środek wspomagający działania tajnej i jawnej policji w jej wysiłkach ukierunkowanych na utrzymanie w ryzach poddanych imperium. Słowo „donos” w dawnym języku rosyjskim oznaczało informację o dokonanym przestępstwie, w języku współczesnym zaś stało się synonimem świadomego przekazywania informacji nieprawdziwych. W radzieckiej przeszłości było kojarzone z przestrzeganiem tajności i złymi intencjami, najczęściej takimi, jak zemsta, chęć osiągnięcia korzyści materialnej, ale także z pobudkami ideowymi. We współczesnym języku rosyjskim istnieje cały szereg określeń bliskoznacznych, którymi posługują się również pisarze: осведомитель, доносчик, агент, информатор, стукач (ostatnie wywodzi się z żargonu złodziejskiego).

W Rosji Radzieckiej fenomen donosicielstwa był na tyle specyficzny i rozpowszechniony, iż przyciąga on uwagę nie tylko pisarzy, lecz także historyków ${ }^{19}$,

19 В. Игнатов, Доносчики в истории России и СССР, Москва 2014. 
socjologów, psychologów ${ }^{20}$ i oczywiście sporej części społeczeństwa. Istnieją oficjalne i nieoficjalne interpretacje donosicielstwa i różnice między nimi są kolosalne. Wiadomo, że polityka rządów radzieckich opierała się na kształtowaniu i umacnianiu w ludziach przekonania, iż żyją oni w najlepszym ze światów, ale istnienie tego świata ciągle jest zagrożone i należy z poświęceniem go bronić. Propaganda państwowa wzniecała i umacniała stany bezustannej podejrzliwości i klasowej nienawiści. Podsycała przekonania o istnieniu wrogów zewnętrznych i wewnętrznych, których należy bezwzględnie unicestwiać. Prawie przez cały okres istnienia ZSRR władza oczekiwała od każdego obywatela pełnej lojalności i oddania ideom, stawiania dobra socjalistycznego państwa ponad wszystkie inne wartości, w tym ponad dobro najbliższych krewnych.

Specyficzne rozumienie dobra i zła, bohaterstwa i jego przeciwieństwa w radzieckiej aksjologii były poddawane ciągłym manipulacjom. Pracownicy milicji wewnętrznej i ich tajni współpracownicy cieszyli się oficjalnym uznaniem, przekładalnym na stosunkowo dobre zarobki oraz różne przywileje i nierzadko, żeby utrzymać swój status quo, składali obwinienia wymyślone, fałszywe po to, by nakręcały puszczoną w ruch machinę represji, dla której funkcjonowania wciąż niezbędni byli nowi podejrzani. Konsekwencje tego faktu to niewiarygodnie rozbudowana sieć agentów służb specjalnych i ich współpracowników wśród cywilów, preparowanie dowodów, zmuszanie aresztowanych drogą tortur do samooskarżeń, rozdmuchiwanie do rozmiarów groźnych przestępstw politycznych drobnych wykroczeń, przejęzyczeń, lekkomyślnie lub bezmyślnie wypowiedzianych słów.

Ogół społeczeństwa niewiele wiedział o metodach pracy funkcjonariuszy bezpieczeństwa. Szerzeniu się donosicielstwa „amatorskiego” sprzyjała oficjalna aprobata i możliwość zaspokojenia tą drogą własnych, nierzadko egoistycznych potrzeb. Donosicielstwu sprzyjała radziecka organizacja bytu, w pierwszej kolejności mieszkania komunalne, w których każdy mógł obserwować każdego ${ }^{21}$, statuty szkolnych i związkowych organizacji, atmosfera

20 Zob. np. В. Нехамкин, Донос как сочиально-психологический феномен, „Историческа психология и социология истории" 2014, т. 7, с. 24 и след.

21 Dostrzegli to pisarze rosyjscy, np. w latach 20. XX wieku M. Zoszczenko, w 60. B. Jampolski i inni. Zob. W. Supa, Жилое пространство и менталитет индивида в рус- 
zebrań partyjnych czy komsomolskich. Dla władzy państwowej w ZSRR donosy były źródłem informacji o społeczeństwie i czynnikiem wykorzystywanym w sterowaniu oraz manipulowaniu nim ${ }^{22}$. Przypadki kar za donosy fałszywe, w różnych okresach historycznych w państwach praworządnych stosowane na dużą skalę, w ZSRR miały miejsce tylko wtedy, gdy z jakichś powodów donosiciele chcieli pogrążyć swoich zwierzchników.

Po rozpadzie ZSRR stosunek do tajnych służb i donosicieli nieprofesjonalnych ulegał różnym modyfikacjom i fluktuacjom. W roku 1991 podjęto uchwałę o rozliczeniu funkcjonariuszy GPU, OGPU, NKWD, prokuratorów oraz sędziów, ale go nie dokonano, głównie z tego powodu, iż objęłoby swym zasięgiem polityków radzieckich, którzy na początku lat 90. minionego stulecia dominowali na rosyjskiej scenie politycznej ${ }^{23}$. Komunistyczne służby bezpieczeństwa zachowały w nowej Rosji uprzywilejowaną pozycję.

Chociaż pewne grupy rosyjskiego społeczeństwa i organizacje pozarządowe, na przykład „Memoriał”, nadal domagają się lustracji, oficjalnie zahamowała ją ustawa z 2004 roku o zaopatrzeniu emerytalnym byłych funkcjonariuszy aparatu państwowego i partyjnego, ustanawiająca dla nich specjalne dodatki. Ustawa ta została odebrana jako specjalna premia państwowa dla sowieckiej nomenklatury. Kryje się za tym przekonanie, że zanim wystąpi wymiana pokoleniowa, koszty społeczne i polityczne rozrachunku z przeszłością w Rosji byłyby zbyt duże. Niezależnie od tego zdarza się jednak, że przy okazji rozpatrywania różnych spraw z niedawnej przeszłości nazwiska katów czy donosicieli ujawnia prasa bądź historycy, a niekiedy, między innymi i z takich powodów, jakie naświetlił Fiodor Dostojewski w Zbrodni i karze - ujawniają się sami. Makanin w Dwóch siostrach... stypologizował różne rodzaje donosicielstwa: z niewłaściwie rozumianych pobudek ideowych (Artiom), z powodu zagubie-

ской прозе XX-XXI веков, [w:] W kręu problemów antropologii literatury. Topos domu. Doświadczanie zamieszkiwania i bezdomności, red. W. Supa, I. Zdanowicz, Białystok 2016, c. 15-30 oraz М. Меерович, Наказанные жилищем. Жилищная политика СССР как средство управления людьми (1917-1937), Москва 2008.

22 Por. F. X. Nèrard, 5\% prawdy. Donos $i$ donosicielstwo $w$ czasach stalinowskiego terroru, przeł. J. Szymańska-Kumaniecka, Warszawa 2008, s. 77 i nast.

23 A. Grajewski, Balast po komunizmie: instytucjonalne rozliczenie komunizmu w krajach Europy Środkowej - opis struktur oraz okoliczności, „Pamięć i Sprawiedliwość” 2013, 12/2, s. 153 i nast. 
nia i niewiedzy (nastoletni Kola Ugriumcew) i trzeci ze świadomego wyboru (ojciec Maksima). Ukazał też konsekwencje donoszenia dla samych donosicieli, ich ofiar i ogółu społeczeństwa, aktualizując w ten sposób problem, który w literaturze rosyjskiej od zarania jej dziejów zajmował bardzo ważne miejsce - chodzi o zakodowany w świadomości wyznawców prawosławia i w kulturze rosyjskiej imperatyw kajania się i pokuty (ros. покаяние) oraz uzyskiwania przebaczania.

Socjolodzy i politycy zwracają uwagę na fakt, iż dla wielu Rosjan nadal jest to temat tabu, że wielu ludzi woli nie znać mechanizmów, a zwłaszcza szczegółów związanych z donosicielstwem, po części dlatego, by uchronić się przed przykrymi doznaniami, zwłaszcza rozczarowaniem w stosunku do znajomych czy krewnych, po części dlatego, że sami donosiciele budzą w nich niechęć, a nawet obrzydzenie. W powieści ilustrują to słowa młodszej z sióstr Tulcewych Inny, skierowane do donosiciela, który opowiada o szczegółach swojej pracy w KGB - „lepiej by pan milczał”.

Jednak niektórzy byli donosiciele czują się winni i chcą być wysłuchani, zrozumiani i usprawiedliwieni. Siergiej Siergiejewicz thumaczy swoje donosicielstwo tym, iż przez całe dorosłe życie tylko wykonywał swoją pracę, robił to, czego od niego wymagano. Dopiero tuż przed przejściem na emeryturę, gdy zresztą dawały już o sobie znać nadchodzące przemiany polityczne, pomyślał o tym, by prosić o wybaczenie swoje ofiary, które przeszły przez piekło śledztwa, obozów i zesłania. I wszyscy mu ,jakby przebaczyli” (ros. Я как бы прощенный). Zwrócono już uwagę24 na istotne znaczenie w tej wypowiedzi partykuły „by”. Jej użycie wskazuje, że przebaczenie nie jest i nie może być pełne, że sam donosiciel nie w pełni rozumie swoją winę, nie czuje się też całkowicie oczyszczony. Z kolei ofiary donosów nie są w stanie zapomnieć o swoich niezawinionych cierpieniach, ale przebaczają. Donosiciel mniejszego kalibru Artiom mówi o potrzebie etapu „pokuty wstępnej” (ros. предпокаяние).

W wielu ludziach drzemie jednak potrzeba sprawiedliwości, właściwej oceny etycznej zarówno poczynań samej władzy, jak i jej sympatyków i ofiar, potrzeba prawdziwej katharsis, zarówno dla donosicieli, jak i pokrzywdzo-

24 А. Токаренко, Конфликт и компромисс в романе В. С. Маканина «Две сестры и Кандинский», „Филологические науки: Вопросы теории и практики” 2014, № 11 (41), c. 195 . 
nych. Niemniej szukanie przebaczenia z własnej inicjatywy, na które zwrócił uwagę Makanin, należy uznać za symptomatyczne i ważne zjawisko. W podobnej sytuacji był zresztą zdradzony przez przyjaciół ojciec sióstr, który po powrocie z zesłania też wybaczył tym, którzy na niego donieśli. Pisarz zwrócił także uwagę na funkcjonowanie syndromu podejrzliwości jako skutku nierozliczenia. Na pierwszy rzut oka odnosi się wrażenie, że Artiom, będący w pewnym stopniu ofiarą wyszkolonych do werbowania współpracowników z zewnątrz (profesjonalistów z KGB) i Ojczulek to zupełnie różni ludzie. Makanin jednak w końcowej scenie powieści, gdy obaj przy jednym stole piją szampana, niweluje różnice między nimi, nawet stawia znak równości i w jednym z wywiadów podkreśla, iż są winni jednakowo z powodu naruszenia zasad etycznych. Uściśla też, iż jego powieść nie jest tylko „balladą o donosicielstwie", lecz zawiera apel do świadomości odbiorcy o krytyczny stosunek do samego siebie, o etyczny (,sołżenicynowski”) maksymalizm.

Według pisarza to utwór o tym, jak sami siebie postrzegamy, sami sobie wybaczamy, jak opowiadając o sobie świadomie czy nieświadomie upiększamy sytuacje ${ }^{25}$. Podobnie jak autorzy współczesnych rosyjskich antyutopii, na przykład postmodernista Władimir Sorokin w Dniu oprycznika oraz niektórzy historycy pisarz sugeruje, iż dzieje niezinterpretowane wszechstronnie i dogłębnie i nieosądzone mogą kiedyś powrócić w równie dramatycznym i tragicznym wymiarze.

W organizacji materiału przedstawionego w omawianej powieści ważną rolę wyznaczono „ciągom (zjawiskom) równoległym”, paralelizmom i sobowtórom ${ }^{26}$. Najważniejsze z nich to dwie siostry jako główne bohaterki, dwa romanse Olgi, dwie rozmowy sióstr przez telefon, dwa typy donosicieli, dwie historycznie i kulturowo zróżnicowane przestrzenie, czyli dwa rosyjskie miasta - Moskwa, gdzie mieszkają Olga i Inna oraz Petersburg, który kocha młodsza z sióstr. Przez tekst powieści niczym refren przewijają się wielokrotnie powtarzane słowa Inny „chcę (jechać) do Petersburga” (ros. в Питер хочy) oraz jej wypowiedzi na temat tego miasta.

25 Баллада о стукачах, chitaem-vmeste.ru/reviews/dve-sestry-i-kandynsky [dostęp: 18.01.2019 r.].

26 Zob. A. Станкевича, Двойничество в романах В. Маканина последнего десятилетия, „Res Humanitariae” 2013, XIV, s. 116 i nast. 
„Obraz” Petersburga zacieśnia więź z Czechowowskim intertekstem i stanowi podstawę zobrazowania ważnej symbolicznej opozycji Moskwa-Petersburg. W rosyjskiej kulturze i literaturze w szczególności Wiktor Toporow wyodrębnił tzw. tekst petersburski, rozumiany jako polifoniczna całość, utworzona przez utwory literackie (dzieła Puszkina, Gogola, Dostojewskiego, Błoka, Biełego, Wołoszyna, Achmatowej i wielu innych rosyjskich twórców) i folklorystyczne, zawierające fragmenty poświęcone fenomenowi tego miasta, a więc jego architekturze, atmosferze, roli w rosyjskiej historii, losom jego mieszkańców itp., mające wieloaspektowe odniesienie do pozatekstowego substratu. Dla Toporowa ,petersburski tekst” stanowi:

...мощное полифоническое резонансное пространство, в вибрациях которого уже давно слышатся тревожные синкопы русской истории и леденящие душу, злые шумы времени²7.

Z petersburskiego konglomeratu wyłania się antytetyczny obraz północnej stolicy Rosji - na jednym biegunie plasują się słowa podziwu i zachwytu (najbardziej cywilizowane, europejskie miasto Rosji), na drugim zaś świadectwa jego wrogości wobec człowieka, powodującej, iż człowiek nigdzie nie jest nieszczęśliwy bardziej, niż w sztucznym grodzie Piotrowym (wyrażane w złorzeczeniach, przekleństwach pod adresem miasta, płaczach). Częścią składową ,petersburskiego nadtekstu” są również „moskiewsko-petersburskie porównawcze teksty" (między innymi autorstwa Bielińskiego, Hercena, Bułharyna, dylogia Biełego Petersburg i Moskwa), eksponujące odmienność rosyjskich stolic. Najczęściej pięknemu Petersburgowi przeciwstawiana jest eklektyczna, bezgustowna, wschodnia (z pierwiastkami azjatyckości) Moskwa.

Jak wiadomo, w Trzech siostrach - „sztuce będącej ekonomicznie napisaną dużą powieścią"28, lejtmotyw stanowią słowa „do Moskwy”, miasta, w którym bohaterki spędziły szczęśliwe dzieciństwo i które ich pamięć koja-

27 В. Топоров, Петербург и Петербургский текст русской литературы, [w:] tenże, Миф. Ритуал. Символ. Образ. Исследование в области мифопоэтического, Москва 1995, c. 259.

28 А. Роскин, А. П. Чехов. Статьи и очерки, Москва 1959, с. 270. 
rzy z ciepłem, słońcem, przyjazną atmosferą, pełnią życia ${ }^{29}$. W porównaniu z marazmem rosyjskiej prowincji to miejsce o wręcz baśniowych możliwościach samorealizacji, tym wspanialsze, że dla Czechowowskich sióstr zupełnie nieosiągalne. Siostry Makaninowskie wyrosły i mieszkają w Moskwie, są samodzielne, mogą w dużym zakresie decydować o swoim życiu, wykorzystywać owe wielkie możliwości.

I w czasach radzieckich, i obecnie Moskwa istotnie oferuje (jak większość stolic) znacznie rozleglejsze niż gdzie indziej możliwości znalezienia pracy, zrobienia kariery, niż prowincja. Posiada lepiej zaopatrzone sklepy, bogatsze życie kulturalne itp. Jednak w Dwóch siostrach ... bliższa od Czechowowskiej wydaje się waloryzacja tego miasta dokonana przez Wieniedikta Jerofiejewa w jego poemacie prozą Moskwa-Pietuszki. Otóż Moskwa (radziecka i postradziecka) to przede wszystkim siedziba obcej i wrogiej dla ludności Rosji władzy, władzy, która zniszczyła przedrewolucyjną tradycję i narzuciła narodowi zgubne dla niego idee oraz pseudowartości. Jej przeciwieństwem w utworze rosyjskiego postmodernisty jest wyidealizowana prowincja, symbolizowana przez odlegle od Moskwy zaledwie o około 200 kilometrów miasto Pietuszki - przestrzeń przedrewolucyjnej rosyjskości, gdzie „wiecznie śpiewają ptaki i kwitnie jaśmin", i gdzie zatrzymałby się zmartwychwstały po raz drugi Chrystus.

W powieści Makanina postsowiecka Moskwa niespokojnych lat 90. XX wieku pozostaje miastem olbrzymich możliwości, ale to także miejsce niebezpiecznych rozgrywek politycznych, działalności mafii, zorganizowanych i niezorganizowanych przestępców, kontrastów społecznych. W swych wypowiedziach bohaterka Makanina degraduje Moskwę, podobnie jak bohater wzmiankowanego wyżej poematu, ale przeciwstawia jej nie rosyjską prowincję, lecz wyidealizowany Petersburg. Dla niej dawna zimowa stolica Rosji pozostaje wcieleniem piękna, szlachetności, wysokiej kultury, wszystkiego, co pozytywne i dobre. Ale najbardziej wyraźnie Makanin (zresztą z dużą dozą ironii) zaakcentował przewijającą się przez „tekst petersburski” męskość Pe-

29 Zob. Г. Хемсо, Символическая структура в «Трех сестрах» Ф. П. Чехова, acta. bibl.u-szeged.hu/711/dissert/slav_009_010_018-041.pdf [dostęp: 02.01.2018 r.] oraz В. Гульченко, «В Москву!». В Москву? Провинция и столица в пьесах Чехова, theatre.sias.ru/ upload/voprosy_teatra/2010_3-4_90-98_gulchenko.pdf [dostęp: 05.01.2018 r.]. 
tersburga, a więc to, czego bardzo brakuje kobietom zarówno w świecie rzeczywistym, jak i powieściowym. W studium Toporowa czytamy: „Петербург вобрал все мужское, все разумно сознательное, все гордое и насильственное в душе России" 30 .

Wychowana na literaturze klasycznej i patrząca na świat z jej perspektywy Inna zachwyca się nie tylko wspaniałymi ulicami i budowlami Petersburga, ale nawet jego „szarymi kamieniami”. Comiesięczne wycieczki (świeckie pielgrzymki) w grupie kochających Petersburg moskwianek doraźnie ratują ją od rozpaczy egzystencjalnej. To ona dostrzega seksualność Petersburga, przekonuje siostrę, że na kobiety oddziałują „fallusopodobne” wieże, iglice, zwodzone mosty... i pomnik braci Orłowów - prawdziwych mężczyzn z epoki Katarzyny II, znaleziony wśród ruin. Poza tym Petersburg kojarzy się z dobrymi zwyczajami, czystością, uczciwymi ludźmi. Oczywiście, spostrzeżenia bohaterki, iż w Petersburgu nie ma donosicieli, bo wszyscy przenieśli się do Moskwy, nie wytrzymałyby testu na prawdziwość, ale wpisują się w mechanizmy waloryzacji rywalizujących ze sobą od dawna rosyjskich stolic. I właśnie z Petersburgiem Inna w najbardziej Czechowowskim w całej powieści monologu wiąże nadzieje na pojawienie się w przyszłości mężczyzn nowego typu, akceptujących w głębi świadomości prawa i potrzeby współczesnych kobiet.

Parafrazując cytowaną wypowiedź badacza twórczości Czechowa, można stwierdzić, że powieść Dwie siostry i Kandynsky to materiał na kilka sztuk teatralnych. Głębi jej treści dodaje przenikanie się i uzupełnianie problemów i obrazów: współczesność jest przedłużeniem przeszłości, miłość jest nierozerwalnie związana z aksjologią ludzkich czynów, synestezyjna, abstrakcyjna sztuka została wykorzystana do charakterystyki rzeczywistości, w tym duchowości (bezduszności) współczesnego człowieka. 
Wanda Supa, Postsowiecka rzeczywistość w świetle „transmetarealizmu”...

\section{Literatura}

Ericson C., Oligarchowie, przeł. H. Jankowska, Warszawa 2014.

Ericson C., Oligarchowie. Pieniądze i władza w kapitalistycznej Rosji, (wywiad), https://www.nesweek.pl/swiat/oligarcgowie-w-rosji [dostęp 12.11.2018 r.].

Jaffe J., Pokolenie Putina. Kim są dziś młodzi Rosjanie?, www.national-geographic/ ludzie/pokolenie-Putina [dostęp 08.11.2018 r.]

Grajewski A., Balast po komunizmie: instytucjonalne rozliczenie komunizmu w krajach Europy Środkowej - opis struktur oraz okoliczności, „Pamięć i Sprawiedliwość" 2013, 12/2.

Kandynsky W., Punkt a linia i płaszczyzna. Przyczynek do analizy elementów malarskich, przeł. S. Fijałkowski, Warszawa 1986.

Melosik Z., Kryzys męskości w kulturze współczesnej, Poznań 2002.

Męskość w kulturze współczesnej, red. A. Radomski, B. Truchlińska, Lublin 2008.

Nèrard F. X., 5 \% prawdy. Donos i donosicielstwo w czasach stalinowskiego terroru, przeł. J. Szymańska-Kumaniecka, Warszawa 2008.

Pietrow N., Rosja traktuje zbrodnie ZSRR jako swoje własne, rozm. M. Puchłowski, https://dzieje.pl/aktualności/nikita-pietrov-rosja-traktuje [dostęp 12.10.2018 r.].

Podrabinek A., Dysydenci. Nieuleczalnie nieposłuszni, Warszawa 2017.

Supa W., Жилое пространство и менталитет индивида в русской прозе XX-XXI веков, [w:] W kręgu problemów antropologii literatury. Topos domu. Doświadczanie zamieszkiwania i bezdomności, red. W. Supa, I. Zdanowicz, Białystok 2016.

Raczyński Z., Między oligarchią a biedotą, [w:] https://www.polityka.pl/swiat/2772640/życie Rosji-między-oligarchią-a biedotą [dostęp 29.11.2018 r.].

Игнатов В., Доносчики в истории России и СССР, Москва 2014.

Маканин В., Две сестры и Кандинский, Москва 2011.

Меерович М., Наказанные жилищем. Жилищная политика СССР как средство управления людьми (1917-1937), Москва 2008.

Роскин А., А. П. Чехов. Статьи и очерки, Москва 1959.

Топоров В., Петербург и Петербургский текст русской литературы, [w:] tenże, Миф. Ритуал. Символ. Образ. Исследование в области мифопоэтического, Москва 1995.

Улицкая Л., Священный мусор, СПб 2012.

Иванова Н., Преодолевшие постмодернизм, «Знамя» 1998, №1, С. 193-204. 
Калашникова О., «Две сестры и Кандинский» в индивидуально-авторском сверхтексте В. Маканина, «Держава та регіони. Серія: Гуманітарні науки" 2018, 1.

Нехамкин В., Донос как социально-психологический феномен, „Историческая психология и социология истории" 2014, Том 7, 2.

Станкевича А., Двойничество в романах В. Маканина последнего десятилетия, „RES Humanitariae” 2013, XIV.

Токаренко А., Конфликт и компромисс в романе В. С. Маканина «Две сестры и Кандинский», «Филологические науки: Вопросы теории и практики» 2014, № 11 (41), с. 194-196.

Шуников В., Синтез эпоса и драмы в романе В. С. Маканина «Две сестры и Кандинский», «Вестник ТБгу», серия «Филология» 2014, 3, с. 146-153.

Баллада о стукачах, «ЧИТАЕМ ВМЕСТЕ» 2011, №10, С. 16-17,

chitaem-vmeste.ru/reviews/dve-sestry-i-kandynsky [dostęp: 18.01.2019 r.].

Гульченко В., «В Москву!». В Москву? Провинция и столица в пьесах Чехова, theatre.sias.ru/upload/voprosy_teatra/2010_3-4_90-98_gulchenko.pdf [dostęp: 05.01.2018 r.].

Ким С., (рецензия), ibookyou/2015/06/24/dve-setry-i-kandynskiy [dostęp: 22.11.2018 r.].

Маканин В., «Две сестры и Кандинский», интервью с писателем 20. 04. 2013, http://nekrasov1979.livejournall.coom/114556.html [dostęp: 04.02.2019 r.].

Маканин В., интервью М. Базаровой, Теперь интеллект не ценится, но терпится, «1.09.2011, www.chaskar.ru/article/vladimir_makanin_sejchas_intellekt [dostęp: 02.01.2019 r.].

Хемсо Г., Символическая структура в «Трех сестрах» Ф. П. Чехова, acta.bibl.uszeged.hu/711/dissert/slav_009_010_018-041.pdf [dostęp: 02.01.2019 r.].

\section{Bibliografia}

Bałłada o stukaczach, «CZITAJEM WMIESTIE» 2011, №10, s. 16-17, chitaem-vmeste. ru/reviews/dve-sestry-i-kandynsky [dostęp: 18.01.2019 r.].

Chiemso G., Simwoliczeskaja struktura w «Triech siestrach» F. P. Czechowa, acta. bibl.u-szeged.hu/711/dissert/slav_009_010_018-041.pdf [dostęp: 02.01.2019 r.].

Ericson C., Oligarchowie, przeł. H. Jankowska, Warszawa 2014. 
Ericson C., Oligarchowie. Pieniądze i władza w kapitalistycznej Rosji, (wywiad), https://www.nesweek.pl/swiat/oligarcgowie-w-rosji [dostęp 12.11.2018 r.].

Jaffe J., Pokolenie Putina. Kim są dziś młodzi Rosjanie?, www.national-geographic/ ludzie/pokolenie-Putina [dostęp 08.11.2018 r.]

Grajewski A., Balast po komunizmie: instytucjonalne rozliczenie komunizmu w krajach Europy Środkowej - opis struktur oraz okoliczności, „Pamięć i Sprawiedliwość" 2013, 12/2.

Gulczenko W., «W Moskwu!». W Moskwu? Prowincyja i stolica wpjesach Czechowa, theatre.sias.ru/upload/voprosy_teatra/2010_3-4_90-98_gulchenko.pdf [dostęp: 05.01.2018 r.].

Ignatow W., Donoscziki w istorii Rossii i SSSR, Moskwa 2014.

Iwanowa N., Prieodolewszyje postmodiernizm, «Znamia» 1998, № 1, s. 193-204.

Kałasznykowa O., «Dwesestry y Kandynskyj» w indywydualno-awtorskom swerchtekste W. Makanyna, 2018, 1 [dostęp: 05.01.2018 r.].

Kandynsky W., Punkt a linia i płaszczyzna. Przyczynek do analizy elementów malarskich, przeł. S. Fijałkowski, Warszawa 1986.

Kim S., (riecenzija), ibookyou/2015/06/24/dve-setry-i-kandynskiy [dostęp: 22.11.2018 r.].

Makanin W., Dwie siestry i Kandinskij, Moskwa 2011.

Makanin W., «Dwie siestry i Kandinskij», intierwju s pisatielem 20.04.2013, http:// nekrasov1979.livejournall.coom/114556.html [dostęp: 04.02.2019 r.].

Makanin W., intierwju M. Bazarowoj, Tiepier' intiełlekt nie cenitsia, no tierpitsia, «1.09.2011»,», wwww.chaskar.ru/article/vladimir_makanin_sejchas_intellekt [dostęp: 02.01.2019 r.].

Melosik Z., Kryzys męskości w kulturze współczesnej, Poznań 2002.

Męskość w kulturze współczesnej, red. A. Radomski, B. Truchlińska, Lublin 2008.

Miejerowicz M., Nakazannyje żyliszczem. Żyliszcznaja politika SSSR kak sriedstwo uprawlenija lud'mi (1917-1937), Moskwa 2008.

Nèrard F. X., 5 \% prawdy. Donos i donosicielstwo w czasach stalinowskiego terroru, przeł. J. Szymańska-Kumaniecka, Warszawa 2008, s. 77 i nast.

Niechamkin W., Donos kak socyalno-psichołogiczeskij fienomien, „Istoriczeskaja psichołogija i socyołogija istorii" 2014, Tom 7, 2.

Pietrow N., Rosja traktuje zbrodnie ZSRR jako swoje własne, rozm. M. Puchłowski, https://dzieje.pl/aktualności/nikita-pietrov-rosja-traktuje [dostęp 12.10.2018 r.].

Podrabinek A., Dysydenci. Nieuleczalnie nieposłuszni, Warszawa 2017. 
Supa W., Żyłoje prostranstwo i mientalitiet indiwida w russkoj prozie $X X-X X I$ wiekow [w:] W kręgu problemów antropologii literatury. Topos domu. Doświadczanie zamieszkiwania i bezdomności, red. W. Supa, I. Zdanowicz, Białystok 2016.

Raczyński Z., Między oligarchią a biedotą, [w:] https://www.polityka.pl/swiat/2772640/życie Rosji-między-oligarchią-a biedotą [dostęp 29.11.2018 r.].

Roskin A., A. P. Czechow. Statji i oczerki, Moskwa 1959.

Stankiewicza A., Dwojniczestwo w romanach W. Makanina posledniego diesiatiletija, „RES Humanitariae” 2013, XIV.

Szunikow W., Sintiez eposa i dramy w romanie W. S. Makanina «Dwie siestry i Kandinskij», «Wiestnik TBGU», sierija «Fiłołogija» 2014, 3, s. 146-153.

Tokarienko A., Konflikt $i$ kompromiss $w$ romanie W. S.Makanina «Dwie siestry i Kandinskij», «Fiłołogiczeskije nauki: Woprosy tieorii i praktiki» 2014, № 11 (41), s. 194-196.

Toporow W., Pietierburg i Pietierburgskij tiekst russkoj litieratury, [w:] tenże, Mif. Rituał. Simwoł. Obraz. Issledowanije w obłasti mifopoeticzeskogo, Moskwa 1995. Ulickaja Ł., Swiaszczennyj musor, SPB 2012. 